\begin{tabular}{|c|c|c|c|}
\hline Article Info & \multicolumn{2}{|c|}{\begin{tabular}{l|l} 
RESEARCH ARTICLE & ARAŞTIRMA MAKALESİ
\end{tabular}} & \\
\hline Title of Article & \multicolumn{2}{|c|}{$\begin{array}{c}\text { Evaluation of Planning Studies for } \\
\text { Sustainable Tourism as a tool of Local } \\
\text { Development: A Study on the Case of } \\
\text { Cittaslow Uzundere }\end{array}$} & \\
\hline $\begin{array}{l}\text { Corresponding } \\
\text { Author }\end{array}$ & \multicolumn{2}{|c|}{$\begin{array}{l}\text { Mustafa ÖZGERİŞ } \\
\text { Atatürk Üniversitesi, Mimarlık ve Tasarım Fakültesi, Peyzaj Mimarlığı Bölümü, } \\
\underline{\text { m.ozgeris@atauni.edu.tr }}\end{array}$} & \\
\hline $\begin{array}{l}\text { Received Date } \\
\text { Accepted Date }\end{array}$ & \multicolumn{2}{|c|}{$\begin{array}{l}15.10 .2020 \\
19.02 .2021\end{array}$} & \\
\hline Author / Authors & $\begin{array}{l}\text { Mustafa ÖZGERIŞ } \\
\text { Faris KARAHAN }\end{array}$ & $\begin{array}{l}\text { ORCID: 0000-0003-1006-9303 } \\
\text { ORCID: 0000-0001-6426-8426 }\end{array}$ & \\
\hline How to Cite & $\begin{array}{l}\text { ÖZGERIŞ, M. and KARAHAN, F. (2 } \\
\text { Sürdürülebilir Turizm için Planlama Çal } \\
\text { Uzundere Örneğinde Bir Araştırma, Voluı }\end{array}$ & $\begin{array}{l}\text { 021). Yerel Kalkınmanın Aracı Olarak } \\
\text { ışmalarının Değerlendirilmesi: Sakin Şehir } \\
\text { ne, 14, Issue 1, Pages, ... }\end{array}$ & $\begin{array}{l}\text { Kent Akademisi } \\
\text { Urban Academy }\end{array}$ \\
\hline
\end{tabular}

\title{
Yerel Kalkınmanın Aracı Olarak Sürdürülebilir Turizm için Planlama Çalışmalarının Değerlendirilmesi: Sakin Şehir Uzundere Örneğinde Bir Araştırma ${ }^{1}$
}

\begin{abstract}
:
This study was carried out in Uzundere (Erzurum) district, which is a tourism center and also Turkey's 11th Slow City. The aim of the study is to evaluate the sustainability of national-regional and local socio-economic, strategic and spatial planning studies affecting Uzundere and the programs for destination formation in relation to tourism and local development, and to determine the equivalence of planning studies in applications. In this context, a sustainability assessment study was conducted with a 40-person focus group. According to the results of the study, national-regional and local planning studies, which are effective in determining the development and development perspective of the district, were not considered sustainable by the focus group in the context of local development and tourism, since they do not have the basic strategies and actions required by sustainability in terms of many criteria. In addition, it was determined that local planning studies could not be put into practice due to the lack of monitoring and evaluation system in some issues. As a result, it has been evaluated that tourism development for Uzundere will serve local development if the basic strategies foreseen by sustainability are developed in the fields of local people, local environment, visitor satisfaction and management and monitoring.
\end{abstract}

KEYWORDS: Local development, slow city, sustainable tourism, planning, Uzundere.

ÖZ:

${ }^{1} \mathrm{Bu}$ çalışma Mustafa ÖZGERIŞ’in Doktora Tezinden üretilmiştir.

${ }^{2}$ Atatürk Üniversitesi, Mimarlık ve Tasarım Fakültesi, Peyzaj Mimarlığı Bölümü, m.ozgeris@ atauni.edu.tr

${ }^{3}$ Atatürk Üniversitesi, Mimarlık ve Tasarım Fakültesi, Peyzaj Mimarlığı Bölümü, fkarahan@ atauni.edu.tr

Evaluation of Planning Studies for Sustainable Tourism as a tool of Local Development: A Study on the Case of Cittaslow Uzundere

Journal of Urban Academy | Volume: 14 Issue: 1 | ISSN: 2146-9229

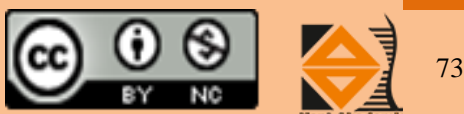


Bu çalışma bir turizm merkezi ve aynı zamanda Türkiye'nin 11. Sakin Şehir'i olan Uzundere (Erzurum) ilçesinde yürütülmüştür. Çalışmanın amacı Uzundere'yi etkileyen ulusal-bölgesel ve yerel ölçekli sosyo-ekonomik, stratejik ve mekânsal planlama çalışmaları ile destinasyon oluşumuna yönelik programların turizm ve yerel kalkınma ile ilişkili olarak sürdürülebilirliğinin değerlendirilmesi ve planlama çalışmalarının uygulamalardaki karşılığının belirlenmesidir. Bu kapsamda 40 kişilik odak grup ile sürdürülebilirlik değerlendirmesi çalışması yürütülmüştür. Çalışmanın sonuçlarına göre ilçenin gelişme ve kalkınma perspektifini belirlemede etkili olan ulusal-bölgesel ve yerel planlama çalışmaları, yerel kalkınma ve turizm bağlamında odak grup tarafından birçok kriter bakımından sürdürülebilirliğin ihtiyaç duyduğu temel strateji ve eylemlere sahip olmadığ 1 için sürdürülebilir olarak değerlendirilmemiştir. Bunun yanında yerel planlama çalışmalarının bazı konularda izleme ve değerlendirme sisteminin olmamasından dolayı uygulamaya geçirilemediği belirlenmiştir. Sonuç olarak Uzundere için turizm gelişiminin, planlama çalışmalarında yerel halk, yerel çevre, ziyaretçi memnuniyeti ve yönetim ve izleme konularında sürdürülebilirliğin ön gördüğü temel stratejilerin geliştirilmesi halinde yerel kalkınmaya hizmet edeceği değerlendirilmiştir.

ANAHTAR KELIMELER: Sakin şehir, sürdürülebilir turizm, planlama, Uzundere, yerel kalkınma.

\section{"Yerel Kalkınmanın Aracı Olarak Sürdürülebilir Turizm için Planlama Çalışmalarının Değerlendirilmesi: Sakin Şehir Uzundere Örneğinde Bir Araştırma”}

\section{GíRIŞ:}

Kalkınma kavramı, gelişmekte olan ülkelerin sosyo-ekonomik, kültürel ve siyasal alanlarda üretim ve milli gelirin arttırılması, sosyal, kültürel ve ekonomik yapının, halkın tüketim, davranış ve dünya görüşlerinin değiştirilerek gelişmiş olan ülkelere yetişme çabalarıdır (Kaypak, 2011). Sanayi Devrimi ve özellikle II. Dünya Savaşı'ndan sonra hız kazanan büyüme ve kalkınma girişimleri, doğa ve doğal kaynaklar üzerinde birçok yıkıcı etkiyi de beraberinde getirmiştir. Başlangıçta göz ardı edilen bu etkiler zamanla çevresel problemlerin yerel olmaktan çıkarak bölgesel ve uluslararası olmaya başlamasıyla birlikte büyüme ve kalkınma kavramlarının çevre ilişkisi içinde ele alınması gerekliliğini doğurmuştur (Tıraş, 2012).

Bu gerekliliğin bir sonucu olarak 1987 yılında sürdürülebilirlik kavramı ortaya çıkmıştır. Norveç Başbakanı Gro Harlem Brundtland'ın başkanlığında Dünya Kalkınma ve Çevre Komisyonu (WCED) tarafından hazırlanan Ortak Geleceğimiz adlı raporla tanımlanan sürdürülebilirlik kavramı, bugünün ihtiyaçlarını ele alırken gelecek nesillerin ihtiyaçlarından ödün vermemek olarak tanımlanmış ve sosyo-kültürel, ekonomik ve çevresel boyutlara dikkat çekilmiştir (Anonymous, 1987). Sürdürülebilirlik kavramı; sürdürülebilir şehirler, sürdürülebilir mekânlar, sürdürülebilir planlama ve tasarımlar, sürdürülebilir tarım, turizm gibi pek çok kavrama temel oluşturmaktadır. Bununla birlikte aslında tüm kavramların ana hedefi, sürdürülebilir kalkınmadır. Sürdürülebilir kalkınma, kalkınma amacıyla yapılan her türlü faaliyette, planlama çalışmalarında, kentleşmede ve alan kullanımlarında doğal ve kültürel peyzaj değerlerini, habitatları ve ekolojik ilişkileri koruma ve kullanım dengesi içerisinde gelecek nesillere aktarmayı amaçlayan ve bunu sağlarken sosyal ve ekonomik faydalar oluşturan bir kalkınma şeklidir. Dolayısıyla sosyal, ekonomik ve çevresel faydalar sağlamayan kalkınma amaçlı faaliyetler sürdürülebilir olmamaktadır. Bu sonuç, özellikle turizmde açık bir şekilde görülebilmektedir. Çünkü turizm arzını oluşturan en temel unsurlar doğal ve kültürel peyzaj değerleridir ve kitlesel ziyaretlere dayalı klasik turizm anlayışı bu değerler üzerinde baskı ve tahribat oluşturarak, turizm alanlarının ziyaretçileri çeken tüm cazibesini yitirmesine neden olabilmektedir (Özkök ve Gümüş, 2009; Acuner, 2015). Bu nedenle turizm arzını oluşturan peyzaj değerlerinin korunması gerekliliği ve turistlerin tercihlerini bozulmamış çevrelerden yana kullanmaya başlamasının da etkisiyle alternatif turizm türleri ortaya çıkmıştır (Kozak ve Bahçe, 2009; Bahtiyar Karadeniz, 2014). Bu alternatif turizm türlerinde biri de Sakin Şehir (Cittaslow) modelidir. Sakin Şehir (Cittaslow) turizmde yerel çevrenin korunması, gastronomik kaynakların ve yeni teknolojilerin kullanımının gerçekleştirilmesi amacıyla 1999 yılında İtalya'da imzalanan Yavaş Şehirler Sözleşmesi' ile kurulmuştur (Miele, 2008; Karakurt Tosun, 2013; Şahin ve Kutlu, 2014). Sakin Şehir anlayış1 çevre, altyapı, sosyal uyum, yerel tarımsal kaynaklar ve işletmeciler, kentsel yaşam, ortaklıklar ve eğitim konularını kapsayan 7 temel kategorideki 72 maddeden oluşan üyelik kriterlerine sahiptir ve sürdürülebilir kalkınmanın hedefleriyle karşılaştırıldığında sosyal, ekonomik ve çevresel boyutlarıyla sürdürülebilirliğe hizmet etmektedir (Bahtiyar Karadeniz, 2014; Şahin, 2017).

$\mathrm{Bu}$ çalışmanın yürütüldüğü Uzundere ilçesinde bölgesel ve yerel planlama çalışmalarında iki ana kalkınma ekseninden biri turizm olarak belirlenmiştir ve turizmde markalaşmış bir destinasyon olması hedeflenmektedir. İlçe 
2013 yılında turizm merkezi olarak ilan edilmiş ve turizmde markalaşma hedefine yönelik olarak 2016 yılında Sakin Şehir ağına dahil olmuştur. Bunun yanında ilçede özellikle son 15 yılda yerel kalkınma amacıyla kamu, yerel yönetim ve sivil toplum kuruluşları işbirliğiyle gerek turizmle ilişkili gerekse de turizmden bağımsız birçok sosyo-ekonomik, mekânsal ve stratejik planlama çalışması, araştırma raporu ve destinasyon oluşumuna yönelik programlar yürütülmüştür. Bununla beraber tüm bu çalışmalar iki ana kalkınma ekseninden biri turizm olan ilçenin turizm arzını oluşturan doğal, kültürel peyzajını ve sosyo-ekonomik yapısını da şekillendirmektedir. Bu noktadan bakıldığında Uzundere'de yürütülen mekânsal, stratejik ve sosyo-ekonomik planlama çalışmaları ile destinasyon oluşumuna yönelik programların sürdürülebilirlik kavramı ile ilişkilendirilmesi gerekmektedir. Çünkü turizm arzını oluşturan kaynak değerlerini olumsuz etkileyen; yerel halk, ziyaretçiler ve yerel çevre için faydalar oluşturmayan planlama çalışmaları turizmi sürdürülebilir olmaktan uzak kılmakta ve bu şekildeki turizm yerel kalkınmaya hizmet etmemektedir.

Bu duruma yönelik olarak çalışmada, Uzundere'nin ulusal-bölgesel ve yerel planlama çalışmaları ile ilçenin mevcut durumunu turizm ve yerel kalkınma ile ilişkili olarak sürdürülebilirlik çerçevesinde değerlendirilmesi ve planlama çalışmalarının uygulamalardaki karşılı̆̆ının belirlenmesi amaçlanmıştır.

\section{Materyal ve Yöntem}

\subsection{Materyal}

Çalışma Türkiye'nin 11. Sakin Şehri olan Erzurum ilinin Uzundere ilçesinde yürütülmüştür. Uzundere ilçesinin gelişme ve kalkınma perspektifini belirleyici nitelikteki ulusal, bölgesel ve yerel ölçekli sosyo-ekonomik, mekânsal ve stratejik planlama çalışmaları, araştırma raporları ve destinasyon oluşumuna yönelik programlar çalışmanın ana materyalini oluşturmaktadır (Tablo 1). Uzundere ilçesinin doğal, kültürel ve sosyo-ekonomik peyzaj kaynak değerleri ise çalışmanın yardımcı materyali olarak kullanılmıştır.

Tablo 1. Çalışmanın ana materyallerini oluşturan planlama çalışmaları ve destinasyon oluşumuna yönelik programlar

\begin{tabular}{|c|c|}
\hline Bölgesel Planlama Çalışmaları & Ulusal Planlama Çalışmaları \\
\hline \multicolumn{2}{|l|}{ DAP Ana Planı } \\
\hline KUDAKA TRA1 Bölge Planı & Onuncu Kalkınma Planı \\
\hline Kuzeydoğu Anadolu Bölgesi İnovasyona Dayalı Turizm Stratejisi & Türkiye Turizm Stratejisi 2023 \\
\hline ve Eylem Planı & Ulusal Kırsal Kalkınma Stratejisi \\
\hline Doğu Anadolu Turizm Geliştirme Projesi & Bölgesel Gelişme Ulusal Stratejisi (2014-2023) \\
\hline Erzurum Doğa Turizmi Master Planı & Turizm Özel İhtisas Komisyonu Raporu \\
\hline \multicolumn{2}{|l|}{ TRA1 Düzey 2 1/100.000 Ölçekli Çevre Düzeni Planı Raporu ve } \\
\hline Plan Hükümleri & Yerel Planlama Çalışmaları \\
\hline DOKAP Ana Planı & \\
\hline DOKA TR90 Bölge Planı & Uzundere Stratejik Gelișme Planı: Vizyon 2023 \\
\hline DOKA Turizm Çalıştay Rapor ve Stratejileri & Uzundere Turizm Master Planı: Vizyon 2023 \\
\hline Erzincan-Erzurum-Kars Kıș Turizm Koridoru Projesi & Uzundere Turizm Merkezi ilanı kararı \\
\hline Palandöken ve Konaklı Turizm Merkezleri ve EJDER 3200 & Uzundere Biyolojik Çeşitlilik Stratejisi ve Eylem \\
\hline Markalaşma Çalışması & Planı \\
\hline Termal Turizm Koridoru Projesi & Tortum Gölü Koruma Amaçlı İmar Planı \\
\hline Hızl Tren Projesi (Erzurum-Sivas-Ankara) & Uzundere Uygulama İmar Planı Raporu \\
\hline Kültür Yolu Projesi (Erzurum-Yakutiye) & \\
\hline
\end{tabular}

Uzundere ilçesi idari olarak Erzurum iline bağlidır ve $40^{\circ} 42^{\prime}-40^{\circ} 26^{\prime}$ kuzey enlemleri ile $41^{\circ} 26^{\prime}-41^{\circ} 47^{\prime}$ doğu boylamları arasındadır (Şekil 1). İlçe coğrafi olarak ise Uluslararası Doğa Koruma Birliği (IUCN) tarafından sahip olduğu biyolojik çeşitliliği ve hassas türleriyle dünyanın 200 önemli ekolojik bölgesi ve 34 sıcak noktasından biri olarak ilan edilen, Kafkasya Ekolojik Bölgesinin batı bölümünü oluşturan Çoruh Havzası'ndaki Tortum Çayı Vadisi içerisinde yer almaktadır (CEPF, 2003). İlçenin iklimi, karasal iklim ile Karadeniz iklimi arasında geçiş özelliği göstermektedir ve jeomorfolojik yapısından dolayı mikroklima özellikleri görülmektedir (Çakmak, 2010). İlçenin jeomorfolojik yapısını dar ve derin vadi tabanları ile tepelik alanlar oluşturmaktadır ve çok çeşitli formasyonlara ait jeolojik oluşumlar bulunmaktadır (Atalay, 1979; Kopar ve Sevindi, 2013; Kopar and Çakır, 2013). 


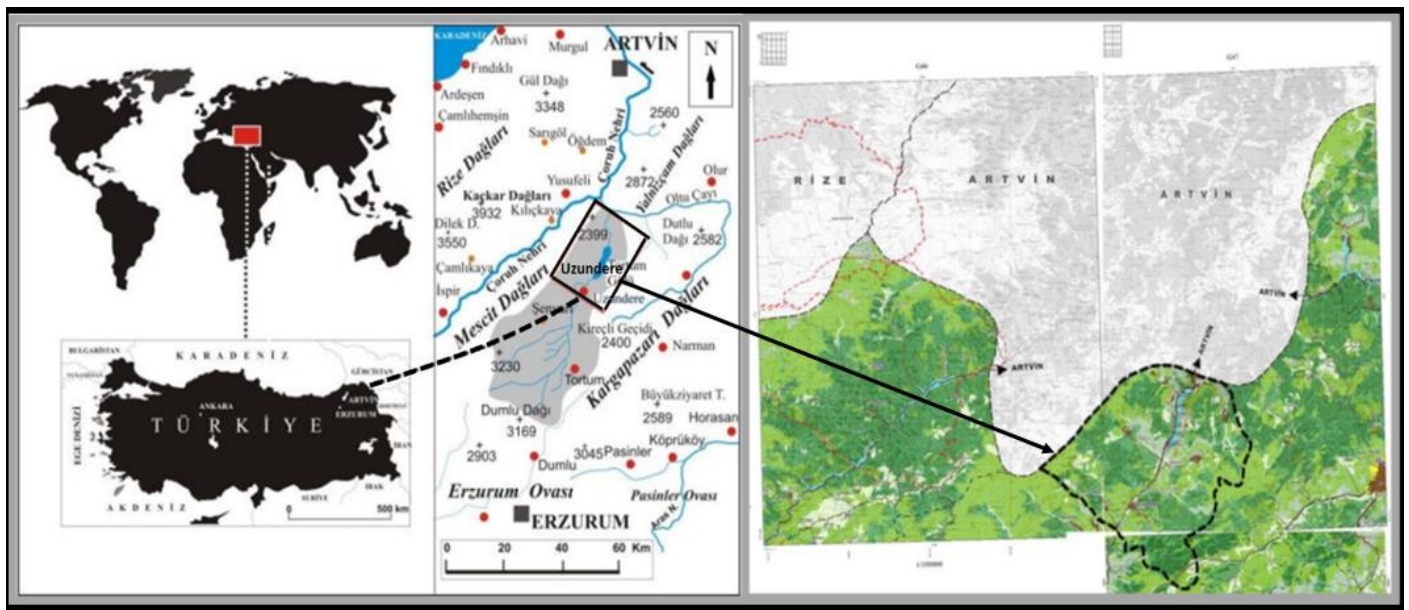

Şekil 1. Çalışma alanı lokasyonu (Karahan et al., 2011)

İlçe florasında 44'ü endemik olmak üzere, 41 odunsu ve 286 otsu bitki türü bulunmaktadır (Anonim, 2013). Bunun yanında 207 yerleşik yaşayan kuş ve 138 kelebek türü bulunmakta ve kurt, yaban kedisi, vaşak, boz ayı, dağ keçisi ve çengel boynuzlu dağ keçisi gibi fauna elemanları ile önemli bir memeli alanı özelliği göstermektedir (Karahan et al., 2017). İlçede çeşitli koruma statüleri ile korunan 24 farklı doğal ve kültürel unsur ve geleneksel olarak yapılan çeşitli festival ve şenlikler yer almaktadır. İlçede genel olarak kırsal doku ve yerel kırsal kültür hakimdir ve yerel kültürün etkilerini geleneksel mimari yapılarda görmek mümkündür. İlçenin 2019 yılı nüfusu 8153'tür ve ilçe ekonomisi ağırlıklı olarak tarıma dayanmaktadır. Tarımsal üretimde tarla tarımı ve meyvecilik hakimdir ve meyvecilikte Erzurum ilçeleri arasında en yüksek üretim yapan ilçe durumundadır (TÜİK 2014). İlçede bir diğer önemli tarımsal faaliyet türü seracılıktır ve ilçede 134 çiftçiye ait 221 adet serada yıllık 780 ton ürün elde edilmektedir (Uzundere Kaymakamlığı, 2018a). Tarımsal ürünler yerel halk tarafından işlenerek pekmez, köme, pestil gibi yöresel ürünlere dönüştürülmektedir (Uzundere Kaymakamlığı, 2018b). Tarımın yanında ilçe ekonomisinde turizm de önemli bir gelir kapısıdır. Turizm işletmeleri genel olarak küçük aile işletmeleri şeklindedir. İlçede konaklama tesisi olarak Uzundere Belediyesi tarafindan yaptırılan fakat daha sonra İlçe Milli Eğitim Müdürlüğüne devredilen Öğretmeni ve özel teşebbüs tarafından işletilen 2 adet pansiyon bulunmaktadır. Bununla beraber ilçede günübirlik ve konaklamalı ziyaretçi sayısına dair herhangi bir ziyaretçi kayıt sistemi bulunmamaktadır. İlçe 2013 yılında 5317 sayılı Bakanlar Kurulu kararıyla turizm merkezi olarak ilan edilmiştir (Resmi Gazete, 2020) ve 2016 yılında Sakin Şehir (Cittaslow) ağına dahil olmuştur. İlçenin turizm arzını oluşturan bazı doğal ve kültürel oluşumları Şekil 2'de verilmiştir. 


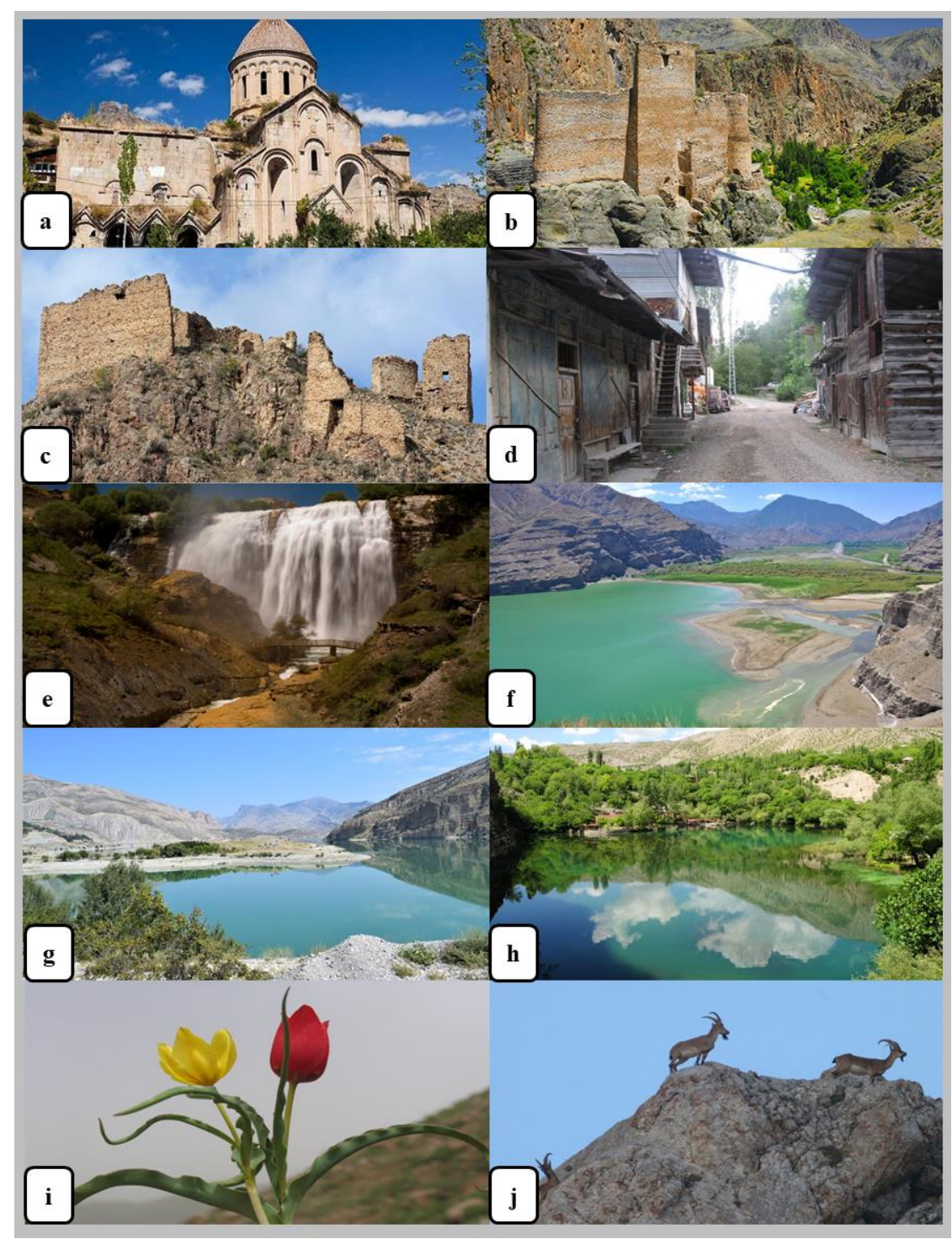

Şekil 2. Uzundere'nin bazı doğal ve kültürel peyzaj kaynak değerleri (a-Öşvank Manastırı b-Engüzekkapı Kalesi c-Sapaca Kalesi d-Geleneksel mimari örnekleri e-Tortum Şelalesi f-Tortum Gölü g-Uzunburun Yarımadası h-Yıkıklar (Yedigöller) i-Tulipa armena Boiss. var. armena j-Rupicapra rupicapra)

İlçenin alan kullanımlarında mevcut kentsel yerleşimler toplamda 67 hektarlık bir alan kaplamakta olup, bunun 37 hektarı net konut alanıdır (Şekil 3). Yerleşimin büyük kısmı ilçe merkezinde diğer bölümü ise merkeze bağlı mahallelerde yoğunlaşmıştır. Mevcut kentsel yerleşimlerde sosyal-kültürel tesis alanı 2,47 hektar, spor tesis alanı 2,83 hektar, mezarlık ve ağaçlandırma alanı 5 hektar, bakdea alanı ise 66,15 hektardır. Kentsel gelişim alanı olarak planlanan bölge Erzurum-Artvin (D950) Karayolu'nun batısında bulunan ve eğimli bir arazide kuzey-güney yönlü bir yerleşime sahip olan Pulur Mahallesi'dir ve imar planlarında kentsel gelişim alanı olarak toplamda 31,6 hektarlık bir alan ayrılmıştır. Orman varlığı 21812,5 hektar olan ilçenin, tarım alanları ise 5500 hektardır. İlçenin çevre il ve ilçelere ulaşımı D-950 Erzurum-Artvin Karayolu üzerinden yapılmaktadır. Kentsel yerleşim içerisindeki yol ve otopark alanları toplamda 110,43 hektarlık bir alan kaplamaktadır. İlçe Erzurum il merkezine $82 \mathrm{~km}$. uzaklıkta olup, en yakın demiryolu hattı ve şehirler arası otobüs terminaline (Erzurum) $84 \mathrm{~km}$, en yakın havaalanına (Erzurum DHMI) ise $88 \mathrm{~km}$. uzaklıktadır. 


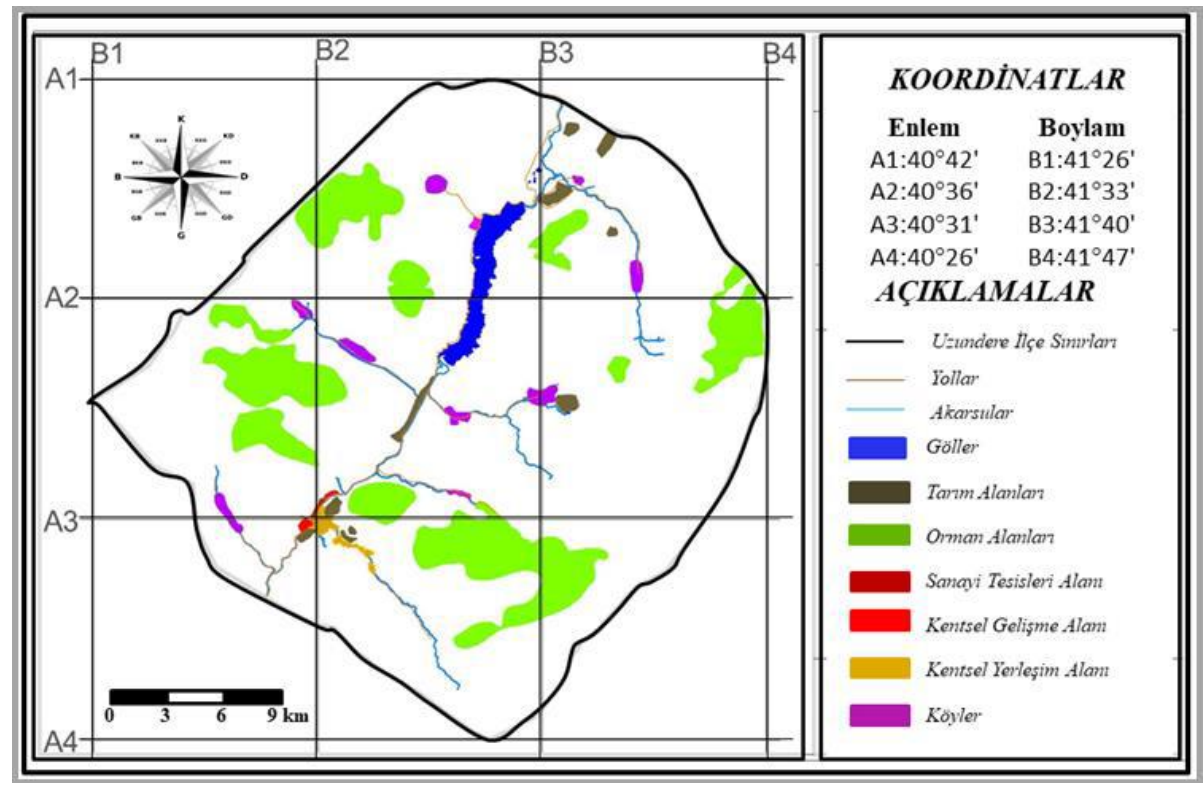

Şekil 3. Uzundere alan kullanımları haritası

\subsection{Yöntem}

Çalışmada veri toplama, analiz ve değerlendirmeye dayalı peyzaj araştırmaları yöntemi kullanılmıştır (Denzin and Lincoln, 2008).

Veri toplama aşamasında Uzundere ilçesini etkileyen ulusal, bölgesel ve yerel ölçekli sosyo-ekonomik, mekânsal ve stratejik planlama çalışmaları, araştırma raporları ve destinasyon oluşumuna yönelik programlar belirlenerek, 'Sürdürülebilirlik Değerlendirmesi Çalışma Formu' oluşturulmuştur. Çalışma formu WTO (2004) ve UNEP and WTO (2005)'in turizm destinasyonları için hazırlamış oldukları sürdürülebilir kalkınma kriter ve göstergelerinden derlenerek, sosyal, ekonomik ve kültürel sürdürülebilirlik; çevresel sürdürülebilirlik; turistik ürün, hizmetler, organizasyon ve pazarlama ve planlama ve izleme olmak üzere dört kategori altında hazırlanmıştır. Kategorileri oluşturan kriter ve göstergeler Tablo 2'de verilmiştir.

Çalışma ile Uzundere ilçesinin mevcut durumu ile ulusal-bölgesel ve yerel ölçekli sosyo-ekonomik, mekânsal ve stratejik planlama çalışmaları, araştırma raporları ve destinasyon oluşumuna yönelik programlar sürdürülebilirlik değerlendirmesine tabi tutulmuştur. Çalışma ilçede yürütülen planlama çalışmaları, projeler, kalkınma girişimleri ve araştırma faaliyetlerine aktif katılım gösteren, dolayısıyla bu çalışmalar hakkında bilgi sahibi olan çeşitli alanlarda faaliyet gösteren 40 kişilik bir odak grup ile (n) ile yürütülmüştür. Çalışmaya başlamadan önce, çalışma formu ve değerlendirilecek olan sosyo-ekonomik, mekânsal ve stratejik planlama çalışmaları, araştırma raporları ve destinasyon oluşumuna yönelik programlar hakkında odak grup katılımcılarına bilgilendirme yapılarak, yardımcı doküman verilmiştir.

Çalışma formundaki her bir soru için odak grup katılımcılarından ilçenin mevcut durumu, ulusal-bölgesel ölçekli planlama çalışmaları ve yerel ölçekli planlama çalışmalarına ayrı ayrı puan vermeleri istenmiştir. Kullanılan yöntem Montenegro Turizm ve Çevre Bakanlığı'nın UNWTO ile birlikte Montenegro-Kolasin Bölgesi için 2007 yılında düzenlemiş olduğu Sürdürülebilir Turizm Çalıştayı'nda kullanılan yöntemden derlenerek geliştirilmiştir (UNWTO, 2007). Benzer çalışmalar daha önce İspanya (Katalonya-El Garraf Natural Park, The Canary Islands), Guatemala (Chiminos Island), Kanada (Cape Breton Island) ve ABD (Arches National Park) gibi turizm bölgelerinde de seçilmiş kriterler üzerine odaklanarak yapılmış olup, WTO tarafından 2004 yılında yayımlanan sürdürülebilirlik göstergeleri k1lavuzunda örnek uygulamalar olarak verilmiştir.

Çalışma formu puanlamasında 'çok düşük seçeneği 1 , düşük seçeneği 2, orta seçeneği 3, yüksek seçeneği 4 ve çok yüksek seçeneği 5' puanı temsil etmiştir. Çalışmanın analiz bölümünde elde edilen veriler analiz edilmiştir. Verilerin analizi IBM SPSS Statistics 24 programı ile yapılarak göstergelerin ait olduğu kriterler için ortalama puan (KO) 
hesaplanmıştır. Çalışma formunda mevcut durum, ulusal-bölgesel planlama çalışmaları ve yerel planlama çalışmaları olarak üç farklı grup olduğundan, gruplara göre kriterlerin almış olduğu cevaplar arasında istatistiki olarak anlamlı bir fark olup olmadığını belirlemek amacıyla One-Way ANOVA (Analyse of Variance) testi ve oluşan anlamlı farkların hangi gruplar arasında gerçekleştiğini belirlemek için Post Hoc test türlerinden Games-Howell ve Tukey testleri yapılmıştır. Analizlerde önem değeri (sig.= p) olarak 0.05 (95\% güven aralığında p=0.05) kullanılmıştır.

Çalışmanın değerlendirme bölümünde analiz edilmiş veriler tartışılarak, planlama çalışmalarının uygulamalardaki karşılığ ve bir turizm merkezi ve Sakin Şehir olan Uzundere'nin sürdürülebilirlik konusundaki eksiklikleri saptanmıştır.

Tablo 2. Turizm destinasyonları için sürdürülebilir kalkınma kriter ve göstergeleri

\begin{tabular}{|c|c|}
\hline \multicolumn{2}{|r|}{ Sosyal, Ekonomik ve Kültürel Sürdürülebilirlik (A) } \\
\hline Kriterler & Göstergeler \\
\hline $\begin{array}{c}\text { Sosyal } \\
\text { Sürdürülebilirlik } \\
\text { (a) }\end{array}$ & $\begin{array}{l}\text { 1.Turizm faaliyetlerinde yerel memnuniyetin dikkate alınması } \\
\text { 2.Ev sahibi toplulukların refahının öncelenmesi } \\
\text { 3.Topluma yeni sosyal hizmetlerin sunulması } \\
\text { 4.Aile refahına önem verilmesi } \\
\text { 5.Kadınlar için firsatların oluşturulması } \\
\text { 6.Çocuk hakları ve çocukların nasıl korunacağı hakkında stratejiler/programların varlığı } \\
\text { 7.Yaşlı ve engelliler için sosyal hizmetlerin varlığı } \\
\text { 8.Uyuşturucu ile mücadeleye yönelik tedbirler/uygulamalar } \\
\text { 9.Kamu sağlığ } 1 \text {, toplum sağlığı, gida güvenliği, iş̧̧i sağlığı ve güvenliği için } \\
\text { oluşturulmuş eğitim ve programların varlığ1 } \\
\text { 10.Yerel gençlere yönelik eğitim ve burs firsatlarının varlığı } \\
\text { 11.Araştırma, eğitim ve küçük işletmeler için destek programlarının varlığı } \\
\text { 12.İ̧̧ amaçlı eğitim firsatlarının varlığı }\end{array}$ \\
\hline $\begin{array}{l}\text { Ekonomik } \\
\text { Sürdürülebilirlik } \\
\text { (b) }\end{array}$ & $\begin{array}{l}\text { 1.Yerel istihdam firsatlarının iyileştirilmesine yönelik stratejiler/programlar } \\
\text { 2.Yerel küçük ve orta büyüklükteki işletmeler için kapasite destekleme ve geliştirme } \\
\text { programlarının varlığı } \\
\text { 3.Çiftçi, zanaatkar ve tedarikçileri turizme dahil etme tedbirleri/uygulamaları } \\
\text { 4.Sezon dışı yerel işsizlik oranları ve mücadele için tedbirler/uygulamalar } \\
\text { 5.İ̧sletmelerde yerel ürünlerin kullanılması ve pazarlanması için tedbirler/uygulamalar } \\
\text { (Ekonomik sızıntının engellenmesi) } \\
\text { 6.Arazi ve konut fiyatlarındaki oluşacak oynamaları dengelemek için } \\
\text { tedbirler/uygulamalar } \\
\text { 7.Turizmle ilgili işlerde yerel halkın istihdamının öncelenmesine yönelik } \\
\text { stratejiler/programlar } \\
\text { 8. Yeni hizmet altyapısı oluşturulması } \\
\text { 9.Turizmin doğa korumaya katkıda bulunmasına yönelik stratejiler/programlar }\end{array}$ \\
\hline $\begin{array}{l}\text { Külttürel } \\
\begin{array}{c}\text { Sürdürülebilirlik } \\
\text { (c) }\end{array}\end{array}$ & $\begin{array}{l}\text { 1.Geleneksel kültürün korunmasına yönelik stratejiler/programlar } \\
\text { 2.Somut olmayan kültürel mirasın korunmasına yönelik stratejiler/programlar } \\
\text { 3.Yerel halka yönelik geleneksel kültürün önemi ve korunması hakkında eğitim } \\
\text { programları }\end{array}$ \\
\hline
\end{tabular}

Çevresel Sürdürülebilirlik (B)

\begin{tabular}{|c|c|}
\hline Kriterler & Göstergeler \\
\hline & yönelik tedbirler/uygulamalar \\
\hline $\begin{array}{l}\text { Doğal ve Külttürel } \\
\text { Miras }\end{array}$ & $\begin{array}{l}\text { 2.Kültürel varlıkların korunmasına yönelik tedbirler/uygulamalar } \\
\text { 3.Nesli tükenmekte olan türlerin korunmasına yönelik tedbirler/uygulamalar }\end{array}$ \\
\hline
\end{tabular}




\begin{tabular}{|c|c|}
\hline $\begin{array}{c}\text { Değerlerinin } \\
\text { Korunması (a) }\end{array}$ & $\begin{array}{l}\text { 4.Kritik ekosistemlerin korunmasına yönelik tedbirler/uygulamalar } \\
\text { 5.Biyoçeşitliliğin korunmasına yönelik tedbirler/uygulamalar } \\
\text { 6.Hava, su ve toprak gibi doğal kaynakların korunmasına yönelik tedbirler/uygulamalar } \\
\text { 7.Doğal peyzaj görüntüsünün korumasına yönelik tedbirler/uygulamalar }\end{array}$ \\
\hline $\begin{array}{c}\text { Kıt Doğal } \\
\text { Kaynakları } \\
\text { Yönetme (b) }\end{array}$ & $\begin{array}{l}\text { 1.Yenilenebilir enerji kaynaklarının kullanımı } \\
\text { 2.Enerji harcamalarında tasarrufa yönelik tedbirler/programlar } \\
\text { 3.Su tasarrufuna yönelik tedbirler/programlar } \\
\text { 4.Planlama ve organize etme sürecinin tüm aşamalarında yeşil ofis uygulamalarını } \\
\text { benimsemek } \\
\text { 5.Enerji koruma programlarının varlığı } \\
\text { 6.Enerji koruma programlarına özel sektörün katılımı } \\
\text { 7.Rekreasyonel ya da içme suyu kaynaklarındaki kirlenmeye yönelik tedbirler/uygulamalar } \\
\text { 8.Daha az karbonlu yakıt kullanımına yönelik tedbirler/programlar } \\
\text { 9.Turizm sektörünün fosil yakıt tüketimine yönelik programlar } \\
\text { 10.Ulaşım için yakıt kullanımı ve alternatif ulaşım planlaması } \\
\text { 11.Kamu ve aktif ulaşım araçlarının kullanımını artırmak ve özel araç kullanım miktarını } \\
\text { azaltmaya yönelik stratejiler/uygulamalar } \\
\text { 12.Atık su yönetimi ve geri dönüştürülmüş gri su planlaması } \\
\text { 13.Kanalizasyon arıtma işlemine yönelik stratejiler/uygulamalar } \\
\text { 14.Katı atık toplama ve ayrıştırmaya yönelik stratejiler/uygulamalar } \\
\text { 15.Katı atıkların depolanması ve geri dönüştürülmesine yönelik stratejiler/ uygulamalar } \\
\text { 16.Tüm mekanlar için bir atık azaltma stratejisinin geliştirilmesi }\end{array}$ \\
\hline $\begin{array}{l}\text { Turizm } \\
\text { Faaliyetleri- nin } \\
\text { Etkileriyle } \\
\text { Mücadele ve } \\
\text { Turistik } \\
\text { Faaliyetlerin } \\
\text { Kontrolü } \\
\text { (c) }\end{array}$ & $\begin{array}{l}\text { 1.Turizm kaynaklı gürültü kirliliği ile mücadeleye yönelik tedbirler/uygulamalar } \\
\text { 2.Turizm yapılanması sürecinde estetik değerlendirmelerin varlığı (Yapılaşmalar fiziksel } \\
\text { ve kültürel bağlamda olmalı; fiziksel olarak çevre ile form, renk ve manzara } \\
\text { bütünleşmesi sağlarken kültürel olarak geleneksel kültür dokusuyla uyumlu olmalı) } \\
\text { 3.Hassas yeşil alanların ve su kütlelerinin gelişmelerden, aşırı veya uygunsuz } \\
\text { kullanımlardan korunmasına yönelik stratejiler } \\
\text { 4.Turistik noktalarda taşıma kapasitesine göre ziyaretçi kabulü } \\
\text { 5.Destinasyonların kullanım yoğunluğunun ölçülmesi ve yönetilmesi }\end{array}$ \\
\hline \multicolumn{2}{|c|}{ Turistik Ürün, Hizmetler, Organizasyon ve Pazarlama Girişimleri (C) } \\
\hline Kriterler & Göstergeler \\
\hline $\begin{array}{c}\text { Turist } \\
\text { memnuniyeti (a) }\end{array}$ & $\begin{array}{l}\text { 1.Turist Memnuniyetin dikkate alınması } \\
\text { 2.Ziyaret beklentilerinin karşılanması } \\
\text { 3.Taciz veya kaygı düzeyinin belirlenmesi ve dikkate alınması } \\
\text { 4.Güvenlik sorunlarından mağdur olan ziyaretçilere yardım etmek için ulusal taahhütlerin } \\
\text { varlığı } \\
\text { 5.Ziyaretçi sağlığı ve güvenliğine yönelik stratejiler/programlar } \\
\text { 6.Engelli kişiler için eğitilmiş turlar / rehberler sunan tur şirketlerinin varlığı }\end{array}$ \\
\hline $\begin{array}{c}\text { Ürün ve } \\
\text { hizmetler (b) }\end{array}$ & $\begin{array}{l}\text { 1.Konaklama, yeme-içme, ulaşım ve diğer hizmetlerin kalitesi } \\
\text { 2.Konaklama, yeme-içme, ulaşım ve diğer tesislerin kapasite ve altyapısını geliştirme } \\
\text { 3.Ürün ve hizmet çeşitliliğinin sağlanması } \\
\text { 4.Turistik faaliyetler için uygun alanların belirlenmesi ve geliştirilmesi } \\
\text { 5.Turistik faaliyetler için uygun rota ve güzergahların oluşturulması ve turların } \\
\text { düzenlenmesi } \\
\text { 6.Turistik alan, rota, güzergah, konaklama ve diğer tesisler için harita ve bilgilendirici } \\
\text { elemanların varlığı (bilgilendirme merkezi, tabela, afiş, broşür v.s) } \\
\text { 7.Turizmi mevsimsellikten kurtarmaya yönelik ürün ve hizmet geliştirme } \\
\text { 8.Resmi belgelendirmeyle varış yerindeki kuruluşların uluslararası sertifikasyona } \\
\text { (EMS, ISO 14000, HACCP vb.) sahip olması } \\
\text { 9.Yerel tarımsal, gastronomik, el-sanatı ürünleri ve hediyelik eşyaların sunulmasına } \\
\text { yönelik stratejiler/programlar } \\
\text { 10.Temel ziyaretçi tesislerinin varlığı (Lavabo, büfe v.b) }\end{array}$ \\
\hline
\end{tabular}


11.Y1l boyunca yeterli altyapı sağlanmasına yönelik stratejiler/programlar 12.Düşük sezon turizminin güçlendirilmesine yönelik stratejiler/ programlar 13.Macera seyahatleri de dahil olmak üzere turistik deneyimlere ve ziyaretçilerin yeteneklerine uygun turlara erişim

1.Hedeflenmiş müşteri kitlesinin varlığ 1

2.Pazarlama etkinliğine yönelik ürün ve hizmetlerin geliştirilmesi

3.Çevre destinasyonlarla koridor, bağlantı ve iş birliği oluşturulmasına yönelik stratejiler/programlar

Organizasyon ve Pazarlama (c)
4.Sürdürülebilir etkinlik çalışmalarına tedarikçileri, bağışçıları ve sponsorları dahil etme

5.Benzer destinasyonlara kıyasla çekiciliğinin tanımlanmış olması

6.Stratejik pazarlama organizasyonu

7.Markalaşma çalışmalarının varlığı

8.Reklam ve promosyon için tahsis edilmiş yıllık pazarlama bütçesinin varlı̆̆ 1

9.Belirlenmiş rota hedeflerinin ve tur organizasyonlarının varlığı

10.Ulusal/uluslararası tur organizasyonlarıyla iș birliği

\begin{tabular}{|c|c|}
\hline \multicolumn{2}{|r|}{ Planlama, Yönetim ve Izleme (D) } \\
\hline Kriterler & Göstergeler \\
\hline $\begin{array}{l}\text { Planlama ve } \\
\text { Yönetim (a) }\end{array}$ & 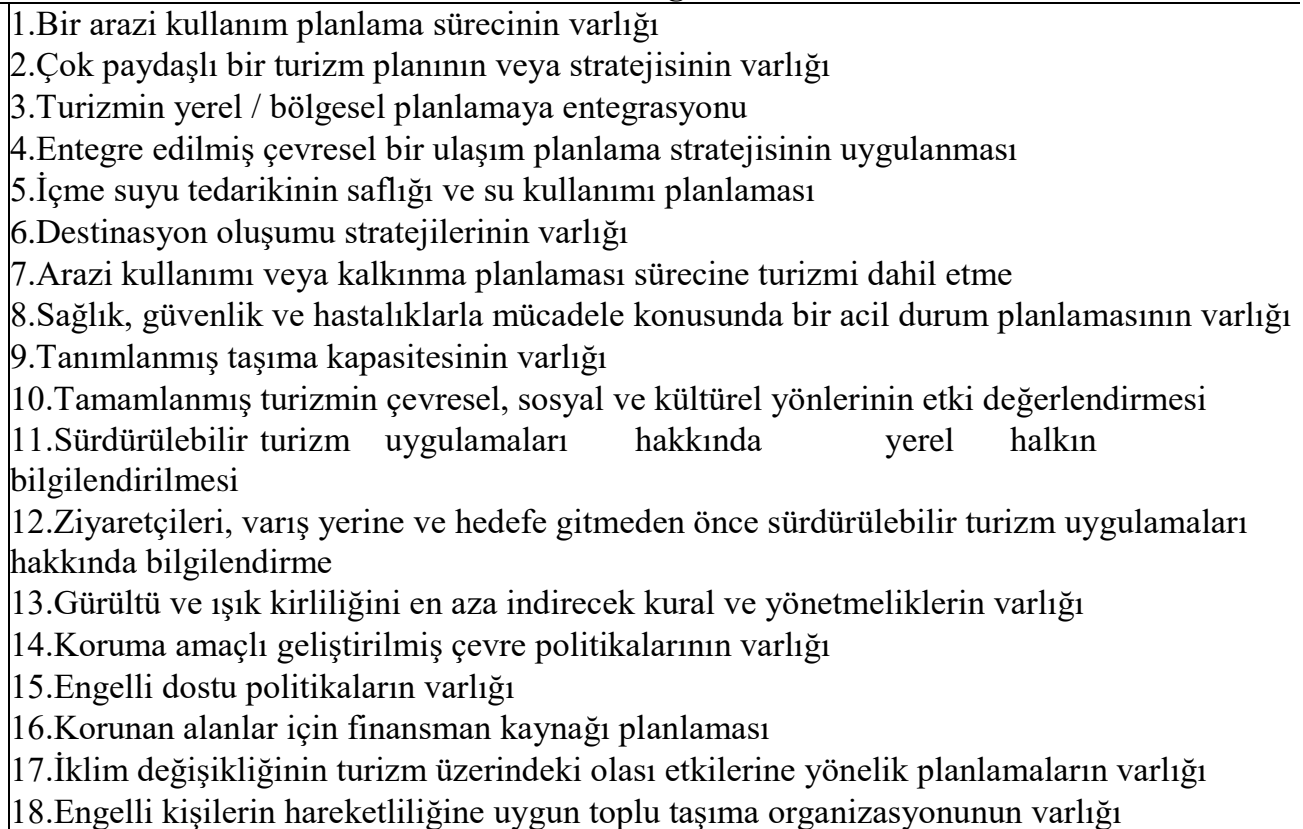 \\
\hline İzleme (b) & $\begin{array}{l}\text { 1.Tüm çevresel elemanlarla ilgili kayıt ve izleme sisteminin varlığı (Su tüketimi ve analiz } \\
\text { değerleri, enerji tüketimi, fauna ve flora elemanlarının sayı ve dağılımı v.b) } \\
\text { 2.Özel sektör ve kamunun turizm organizasyonunda yer alması } \\
\text { 3.Koruma alanlarında turizm faaliyetlerini koordine eden koruma kuruluşları ile izleme ve } \\
\text { yönetim planlarını varlığı } \\
\text { 4.Ziyaretçi kayıt sisteminin varlığı } \\
\text { 5.Turist memnuniyetini geliştirme ve beklentilerin karşılanmasına yönelik izleme sisteminin } \\
\text { varlığı } \\
\text { 6.Planlamalarda turizm gelişimini kontrol altına almak için belirlenmiş kriterler } \\
\text { 7.Tüm alanlarda olumlu bir rol oynamak için saygın çevre grupları ile iş birliği } \\
\text { 8.Geliştirilen ve kullanılan planı değerlendirmek için belirlenen performans göstergelerinin } \\
\text { varlığ1 } \\
\text { 9.İklim değişikliği konusunda kamu, özel sektör ve ziyaretçiler arasında farkındalık } \\
\text { yaratmak için programlar } \\
\text { 10.İçme ve rekreasyonel su kalitesi hakkında halka açık izleme sistemi } \\
\text { 11.Stratejik planlama süreçlerine sürdürülebilirlik özellikleri hakkında bilgi veren ajansların } \\
\text { varlığ1 }\end{array}$ \\
\hline
\end{tabular}




\section{Araştırma Bulguları ve Tartışma}

Çalışmanın gerçekleştirildiği 40 odak grup katılımcısına ait demografik bilgiler Tablo 3 'te verilmiştir.

Tablo 3. Odak grup katılımcılarının demografik bilgileri

\begin{tabular}{|c|c|c|}
\hline Özellikle & Alt Özellikler & n \% \\
\hline Cinsiyet & Erkek & 2767,5 \\
\hline & Kadın & 1332,5 \\
\hline Yaş & $16-25$ & 00 \\
\hline & $26-35$ & 1127,5 \\
\hline & $36-45$ & 2357,5 \\
\hline & $46-55$ & 37,5 \\
\hline & 56 ve üstü & 37,5 \\
\hline Eğgitim & İlköğretim & 00 \\
\hline Durumu & Lise & 25,0 \\
\hline & Ön Lisans-Lisans & 1230,0 \\
\hline & Lisansüstü & 2665,0 \\
\hline Gelir & 2000 TL alt1 & 00 \\
\hline & 2001-5000 TL aras1 & 1230,0 \\
\hline & $5001-10.000 \mathrm{TL}$ aras1 & 1947,5 \\
\hline & $10.0001 \mathrm{TL}$ üstü & 922,5 \\
\hline Faaliyet & Akademisyen & 1742,5 \\
\hline Alanı & Kalkınma Ajansı Çalışanı & 512,5 \\
\hline & Yerel Yönetim ve Kamu Çalışanı & 37,5 \\
\hline & Yerel Siyasetçi & 37,5 \\
\hline & Yerel Turizmci ve Esnaf & 25,0 \\
\hline & Yerel STK Mensubu & 12,5 \\
\hline & Doğa Sporcusu (STK) & 25,0 \\
\hline & Öğretmen-Proje Uzmanı & 25,0 \\
\hline & Peyzaj Mimarı (Doktora Öğr.-Serbest Ç.) & 12,5 \\
\hline & Kadın Girişimci & 25,0 \\
\hline & Muhtar & 12,5 \\
\hline & Eski Bld. Bşk. & 12,5 \\
\hline Toplam & & 40100 \\
\hline
\end{tabular}

Tablo 3'e göre odak grup katılımcılarının 67\%'si erkek, 32\%'si ise kadındır. Büyük çoğunluğu lisansüstü (65\%) eğitim seviyesine sahipken yine önemli bir bölümünü akademisyen (42,5\%) grubu oluşturmuştur.

Uzundere ilçesinin mevcut durum (UMD), ulusal-bölgesel planlama çalışmaları (UBPÇ) ve yerel planlama çalışmalarının (YPÇ) sürdürülebilirlik kriterleri bakımından almış olduğu ortalama puanlar ve ANOVA analizi sonuçları Tablo 4' te verilmiştir.

Tablo 4. Sürdürülebilirlik kriter ve göstergelerinin aldığı ortalama puanlar ve ANOVA testi sonuçları

\begin{tabular}{llllll}
\hline & Kriterler & UMD & UBPÇ & YPÇ & p \\
\hline A & Sosyal, Ekonomik ve Kültürel Sürdürülebilirlik & 2,499 & 3,098 & 2,900 & -
\end{tabular}




\begin{tabular}{llllll}
$\mathrm{Aa}$ & Sosyal Sürdürülebilirlik & $2,579^{*}$ & $3,189^{*}$ & 2,883 &, 000 \\
$\mathrm{Ab}$ & Ekonomik Sürdürülebilirlik & $2,236^{*}$ & $2,922^{*}$ & 2,552 &, 001 \\
$\mathrm{Ac}$ & Kültürel Sürdürülebilirlik & $2,683^{*}$ & 3,183 & $3,266^{*}$ &, 017 \\
\hline $\mathrm{B}$ & Çevresel Sürdürülebilirlik & 2,181 & 3,064 & 2,822 & - \\
$\mathrm{Ba}$ & Doğal ve Kültürel Miras Değerlerinin Korunması & $2.507^{* *}$ & $3,332^{*}$ & $3,417^{*}$ &, 000 \\
$\mathrm{Bb}$ & Kıt Doğal Kaynakları Yönetme & $1,831^{* *}$ & $2,951^{*}$ & $2,375^{*}$ &, 000 \\
$\mathrm{Bc}$ & Turizm Faaliyetlerinin Etkileriyle Mücadele ve Turistik & $2,205^{* *}$ & $2,910^{*}$ & $2,675^{*}$ &, 000 \\
& Faaliyetlerin Kontrolü & & & & \\
\hline $\mathbf{C}$ & Turistik Ürün, Hizmetler, Organizasyon ve Pazarlama & 2,535 & 3,241 & 2,951 & - \\
$\mathrm{Ca}$ & Turist Memnuniyeti & $2,537^{*}$ & $3,116^{*}$ & 2,812 &, 009 \\
$\mathrm{Cb}$ & Ürün ve Hizmetler & $2,705^{* *}$ & $3,521^{*}$ & $3,259^{*}$ &, 000 \\
$\mathrm{Cc}$ & Organizasyon ve Pazarlama & $2,365^{*}$ & $3,087^{*}$ & 2,782 &, 001 \\
\hline $\mathbf{D}$ & Planlama, Yönetim ve İzleme & $2,247^{*}$ & $2,907^{*}$ & 2,563 & - \\
$\mathrm{Da}$ & Planlama ve Yönetim & $2,416^{*}$ & $3,123^{*}$ & 2,765 &, 000 \\
$\mathrm{Db}$ & İzleme & $2,077^{*}$ & $2,691^{*}$ & 2,361 &, 006 \\
\hline $\mathrm{x}^{*}, \mathrm{y}^{*}, \mathrm{z}$ & *ise z, hem x, hem de y ile anlamlı bir şekilde farklılaşmıştır & & & \\
$\mathrm{x}^{*}, \mathrm{y}^{*}$ ise sadece x ve y anlamlı bir şekilde farklılaşmıstır & & & & \\
\hline
\end{tabular}

Tablo 4'e göre göre sosyal, ekonomik ve kültürel sürdürülebilirlik kriterleri yönünden ulusal-bölgesel planlama çalışmaları yerel planlama çalışmaları ve Uzundere mevcut durumdan anlamlı bir şekilde farklılaşmıştır. Bu kriter bakımından ulusal-bölgesel planlama çalışmaları, Uzundere mevcut durum ve yerel planlama çalışmalarından daha yüksek bir ortalama puan almıştır. Bu durum için ulusal-bölgesel planlama çalışmalarının, Uzundere mevcut durum ve yerel planlama çalışmalarına göre sosyal ve ekonomik olarak daha sürdürülebilir bir ortam sağladığı sonucu çıarılmıştır. Yerel planlama çalışmaları içerisinde Uzundere Stratejik Gelişme Planı ve Uzundere Turizm Master Planı'nda sosyo-ekonomik sürdürülebilirliğe katkı sağlayabilecek bazı stratejiler ve eylemler bulunmasına rağmen bu planlar sürdürülebilir turizmin öngördüğü; işletmelerde yerel ürünlerin kullanılması, arazi ve konut fiyatlarındaki oluşacak oynamaların dengelenmesi ve sezon dışı yerel işsizlik ile mücadele gibi strateji ve tedbirlere sahip değildir. Oysa sürdürülebilir turizm, turizmin ihtiyaçlarını karşılarken, yerel halk için sosyo-ekonomik faydalar oluşturan ve gelecek nesiller için doğal ve kültürel çevreyi korumayı hedefleyen bir turizm şeklidir. Sürdürülebilir turizmde yerel halkın ekonomik durumunun geliştirilmesinde, bölgedeki mevcut ekonomik faaliyetlerin desteklemesi, yerel tarımsal, gastronomik ve el sanatı ürünlerinin üretiminin desteklenerek yeni istihdam firsatlarının oluşturması etkilidir (Farsani et al., 2011). Bu aynı zamanda Sakin Şehir anlayışıyla da uyumlu bir turizm şeklidir. Çünkü Sakin Şehir anlayışı fast food kültürüne karşı olarak ortaya çıkmıştır ve turizmde yerel kaynakların (çevresel, tarımsal, gastronomik vb.) kullanımını esas almaktadır (Şahin ve Kutlu, 2014). Bu durum zaten sosyal ve ekonomik boyutlara sağladığı katkılar ile Sakin Şehir anlayışının sürdürülebilir kalkınmaya hizmet etmesini sağladığından dolayı, 'Sakin ŞehirSürdürülebilir Kalkınma' ilişkisinin kurulduğu konuların arasında gelmektedir. Bu noktadan hareketle Uzundere'de tarımsal, gastronomik ve el sanatı ürünleri ile kadın emeğine dayalı üretimin desteklenerek turizm kapsamında değerlendirilmesinin ve ilçedeki geleneksel sivil mimari örneklerinin yerel halk tarafından işletilen ev pansiyonculuğu şeklinde kullanılmasının yerel halk için sosyo-ekonomik faydalar oluşturacağı söylenebilir. Zaten yerel kültürü yansıtan geleneksel sivil mimari örnekleri, diğer tescilli tarihi kültürel yapılar, somut olmayan mirasın korunmasını ön gören strateji ve tedbirler yerel planlama çalışmalarında yerini almıştır. Özellikle Uzundere Biyolojik Çeşitlilik Stratejisi ve Eylem Planı bu konuda sürdürülebilir bir yaklaşım sergilemektedir ve çalışmanın sonuçlarına göre de yerel planlama çalışmaları kültürel sürdürülebilirlik kriteri yönünden yükseğe yakın bir ortalama puan almıştır. Bununla beraber Uzundere mevcut durum kültürel sürdürülebilirlik kriteri yönünden yerel planlama çalışmalarından negatif yönde anlamlı bir şekilde ayrışmıştır. Bu durum yerel planlama çalışmalarının bu konuda uygulamaya geçmediğini göstermektedir. 
Çevresel sürdürülebilirliğe ait doğal ve kültürel miras değerlerinin korunması kriteri yönünden en yüksek ortalama puanı, yerel planlama çalışmaları almıştır. Bu kriter bakımından Uzundere mevcut durum, yerel ve ulusal-bölgesel planlama çalışmalarından negatif yönde anlamlı bir şekilde farklılaşmıştır. Kıt doğal kaynakları yönetme ile turizm faaliyetlerinin etkileriyle mücadele ve turistik faaliyetlerin kontrolü kriterleri bakımından en yüksek ortalama puanları ulusal-bölgesel planlama çalışmaları almasına rağmen; kriter ortalamaları, orta seviyenin altında kalmışıı. Bu kriterler bakımından Uzundere mevcut durum, yerel ve ulusal-bölgesel planlama çalışmalarından negatif yönde anlamlı bir şekilde ayrışmıştır. Bu durum, planlama kararlarının uygulamaya geçirilemediği şeklinde yorumlanmıştır. Turizm çevresel olarak çok yönlü etkilere sahiptir. Günümüzde ekonomiler için önemli bir bileşen olmasına rağmen, turizm faaliyetlerinin çevreye zarar vermemesi gerekir. Çünkü turizmin pazarlamasında çekiciliği oluşturan ana unsur bozulmamış bir doğadır (Page and Connell, 2006). Ekolojik hassasiyetler gözetilerek ve sürdürülebilir bir planlama anlayışıyla gerçekleştirilen turizm gelişiminde, turizmin etkileri olumlu yönde seyredebilirken; aksi yöndeki turizm gelişimi olumsuz çevresel etkileri ve sağlıksız bir büyümeyi beraberinde getirmektedir. Plansız turizm yatırımları ve turizm gelişimi kısa vadede kazançlar getirse de uzun vadede ciddi sorunlara yol açabilmektedir. Çünkü kötü tasarlanmış ve plansız bir turizm gelişimi, ziyaretçileri çeken ve turizm arzını oluşturan doğal ve kültürel peyzajı yipratabilmektedir (Inskeep, 1991).

Günümüzde dünyanın konuştuğu çevresel olayların başında küresel ısınma ve iklim değişikliği gibi küresel ölçekli çevresel sorunlar ve bunların bölgesel ve yerel ölçekli yıkıcı etkileri gelmektedir. Bu etkilerin sonuçlarını en aza indirmek için sürdürülebilir mekânlar ve tasarımlar, fosil yakıtların tüketiminin azaltılması, enerjinin verimli kullanımı ve alternatif enerji kaynakları, atık yönetimi (ayrıştırma, dönüştürme ve yeniden kullanma), su yönetimi (arz ve verimli su kullanımı) ve gıda güvenliği dünyanın spesifik olarak odaklandığı konulardandır. Bu odak noktaları göz ardı eden her planlama ve tasarım çalışması sürdürülebilir olmaktan uzaktır. Aynı şekilde bu noktalara odaklanmayan turizm destinasyonları da sürdürülebilir turizm gelişimi ve kalkınmayı yakalayamayacaktır. Her ne kadar çalışma kapsamında değerlendirilen 10. Kalkınma Planı ve DAP Ana Planı gibi ulusal-bölgesel düzeyli ve Uzundere Stratejik Gelişme Planı, Uzundere Turizm Master Planı gibi yerel düzeyli planlama çalışmalarında sürdürülebilir kalkınma, iklim değişikliği, çevre, doğal kaynakların etkin kullanımı ve yeşil büyüme kavramlarına atıfta bulunulsa da fosil yakıt tüketiminin azaltılması ve alternatif enerji kaynaklarının kullanımı ile ilgili her hangi bir strateji ve eyleme vurgu yapılmamaktadır. Bununla beraber 2019-2023 yılları arasını kapsayan 11. Kalkınma Planı'ndaki sürdürülebilirlik ve sürdürülebilir kalkınma vurguları son derece önemlidir (SBB, 2020). Uzundere'de özellikle konutlarda güneş enerjili su 1sıtma sistemleri yoğun bir şekilde kullanılmaktadır ve güneş enerjili sistemlerin kamusal alanlarda ve konutlarda kullanımının yaygınlaştırılması, Uzundere için çevresel sürdürülebilirliğe katkı sağlayabilir. Buna karşılık, atık yönetimi Uzundere için ele alınması gereken bir konudur. Çünkü Uzundere atık depolamada hâlâ vahşi depolama yöntemini kullanmaktadır. Bölgesel planlarda özellikle katı atık depolama ve ayrıştırma ile ilgili bazı hedefler olmasina rağmen bunlar henüz uygulamaya geçirilememiştir. Ancak son dönemlerde, ulusal çapta yürütülen sıfır atık gibi bazı programlar mevcuttur. Henüz toplum nezdinde evsel atıklar için uygulanmasa da bu tür programlar özellikle atık yönetimi (atık ayrıştırma ve dönüştürme) konusunda kamu kurumları, belediyeler ve toplum için bir farkındalık oluşturabilir. Bu konuda yapılacak girişimler, Uzundere için ulusal programlarla uyumlu olarak, bölgesel planlama hedeflerine ulaşmak için bir firsat penceresi aralayabilir. Bunun yanında ilçenin Sakin Şehir birliğine üye olması, sürdürülebilir turizm konusunda Uzundere için bir sinerji oluşturabilir. Kuşkusuz Sakin Şehir birliğinin üyelik kriterleri içerisinde çevresel sürdürülebilirliğe hizmet edebilecek nitelikte ve sürdürülebilir turizm kriterleri ile uyumlu birçok politika bulunmaktadır. Özellikle Sakin Şehir'in hava, su, gürültü ve görüntü kirliliğinin önlenmesi, enerjinin verimli kullanımı ve yenilenebilir enerji kaynakları, kent içi yeşil alanların artırılması ve yeşil sosyal donatı alanlarının oluşturulması ve bisiklet gibi alternatif ulaşım araçlarının kullanımının teşviki gibi politikaları çevresel sürdürülebilirlik açısından önemlidir.

Turist memnuniyeti kriteri bakımından Uzundere mevcut durum ve yerel planlama çalışmaları düşük, ulusal ve bölgesel planlama çalışmaları ise ortanın üzerinde bir puan almıştır. WTO turist memnuniyetini ziyaretçiler için cinsiyet, ırk, engellilik ya da farklı bir şekilde her hangi bir ayrımcılık yapmadan güvenli ve tatmin edici bir deneyim sağlamak olarak tanımlamaktadır (UNEP and WTO, 2005). Kozak (2001) ise ziyaretçi memnuniyeti ile yeniden ziyaret etme arasında anlamlı bir ilişki olduğunu belirtir (İpar ve Doğan, 2013). Bu bir turizm merkezinde ziyaretçi sürdürülebilirliği açısından önemli ilke olmasına rağmen Uzundere için geliştirilmesi gereken bir konu olarak ön plana çıkmaktadır.

Ürün ve hizmetler kriteri bakımından, ulusal ve bölgesel planlama çalışmaları ile yerel planlama çalışmaları ortanın üzerinde bir puan alırken; Uzundere mevcut durum, düşük bir puan almıştır ve Uzundere mevcut durum, ulusalbölgesel ve yerel planlama çalışmalarından negatif yönde anlamlı bir şekilde farklılaşmıştır. Bu durum yerel planlama 
çalışmalarının ulusal ve bölgesel planlama çalışmaları ile uyumlu olduğunu; fakat tam olarak uygulamaya geçirilemediğini göstermektedir. Ancak yerel planlama çalışmalarında turizmi mevsimsel olmaktan çıkaracak ürün ve hizmetler, ziyaretçi türüne uygun turlara erişim ve turizm işletmelerinin uluslararası sertifikasyonuna yönelik strateji ve eylemlerin yetersiz oluşu turizmin sürdürülebilirliği açısından olumsuz bir durum olarak öne çıkmaktadır. Uzundere'de turizm faaliyetleri genel olarak ilkbahar-sonbahar mevsimleri arasındaki altı aylık süreçte aktif durumda, kalan altı aylık süreçte ise düşük sezon şeklindedir. Son dönemlerde kış sezonunda buz tırmanışı gibi etkinlikler yapılsa da bu etkinlikler altı aylık düşük sezonu hareketlendirmeye yeterli gelmemektedir. Oysa ki Uzundere'nin zengin jeolojik, jeomorfolojik ve hidrografik oluşumları, çevresinden ayrışan iklim özellikleri, sahip olduğu etkileyici manzaralar, flora, fauna elemanları, tescilli ve tescilsiz tarihi-kültürel eserler, yerel kültürün bir yansıması olan geleneksel sivil mimari örnekleri, gastronomik ve tarımsal ürünleri, yerel kültürel festival ve şenlikleri özellikle kadın emeğine dayalı el sanatı ürünlerine dayalı peyzaj kaynak değerleri turizmin çeşitlendirilmesi ve turizm etkinliklerinin yıl boyuna yayılması için yeterli düzeydedir (Özgeriş and Karahan, 2020). İlçenin turizm arzını oluşturan bu zengin doğal, kültürel ve sosyo-ekonomik kaynak değerlerinin doğru bir planlama anlayışı ile turizme dahil edilmesi hem turizmin sürdürülebilirliğine hizmet edebilir hem de yerel kalkınma açısından bir firsat kapısı aralayabilir. Kültürel kaynaklar ve tarımsal ürünler zaten özellikle kırsal alanlar açısından turizm ürün çeşitlendirmesi için iyi bir yoldur. Örneğin, BM Ekonomik ve Sosyal İşler Departmanı tarafından hazırlanan en iyi sürdürülebilir turizm uygulamaları arasında yerini alan İran'ın Matin Abad organik tarım ve çöl kampı yerel kaynakların bütünleştirilerek yerel kalkınmanın bir aracı hâline getirilmesi bakımından iyi bir örnektir. Bu kampta; sivil mimari, yerel kültür, enerji ve atık yönetimi gibi çevresel koruma eylemleri ve organik tarım birleştirilerek turizm ürün çeşitlendirilmesi yapılmaktadır (Wei, 2012). Uzundere'nin sahip olduğu benzer potansiyellerin de benzer şekillerde değerlendirilmesi, hem turizm ürün çeşitlendirmesi hem de yerel kalkınma açısından faydalı bir model olabilir.

Organizasyon ve pazarlama kriteri yönünden ise Uzundere mevcut durum ve yerel planlama çalışmaları düşük bir ortalama puan alırken; ulusal ve bölgesel planlama çalışmaları, ortanın üzerinde bir ortalama puan almıştır ve Uzundere mevcut durum, ulusal-bölgesel planlama çalışmalarından negatif yönde istatistiki olarak anlamlı bir şekilde farklılaşmışırı. Bu kriter bakımından Uzundere için hedeflenen bir müşteri kitlesinin, rota ve tur organizasyonlarının, tur operatörleriyle iş birliğinin ve pazarlama stratejilerinin yetersizliği öne çıkan başlıca eksiklikler olarak görülmektedir. Özellikle tur operatörleri ve seyahat acenteleri ile iş birliği bir destinasyonun marka olarak dikkat çekmesi ve başarısı üzerinde büyük bir öneme sahiptir (Holloway, 2009). Bu noktada Uzundere için çevre turizm merkezlerinin varlığı bir firsattır. Erzurum-Erzincan-Kars kış turizm koridoru projesi, Sivas-Erzincan-Kars hızlı tren projesi, Erzurum-Yakutiye cazibe merkezi projesi, EJDER 3200 markalaşma çalışması, termal turizm koridoru projesi ve DOKA Arap turizmini geliştirme projesinin bölgesel olarak bir turizm hareketliliği oluşturması beklenmektedir. Uzundere için çevre turizm merkezlerine göre bir ürün farklılaştırması ve marka algısı oluşturabilirse seyahat acentaları-tur operatörleri ve bölge otelleri ile iş birliği geliştirilerek günübirlik ve konaklamalı turlar ile yöreye ziyaretçi çekilebilir.

Planlama, yönetim ve izleme yönünden Uzundere mevcut durum, ulusal-bölgesel ve yerel planlama çalışmaları düşük bir ortalama puan almıştır. Planlama ve yönetim kriteri bakımından ulusal ve bölgesel planlama çalışmaları ortanın üzerinde bir ortalama puana sahip olurken, Uzundere mevcut durum ve yerel planlama çalışmaları düşük bir ortalama puana sahip olmuştur. Bu kriter bakımından Uzundere mevcut durum, ulusal-bölgesel planlama çalışmalarına göre negatif yönde anlamlı bir şekilde farklılaşmıştır. Sürdürülebilir turizm gelişimini sağlamak için turizm sektörünün tüm paydaşlarını bir araya getirerek etkili politika ve planlar üretilmesine ihtiyaç duyulmaktadır. UNWTO Sürdürülebilir Turizm Gelişimi Departmanı, turizm destinasyonları için hazırlamış olduğu sürdürülebilir turizm kılavuzunda planlama, yönetim ve izleme süreçlerine özellikle dikkat çekmektedir (UNWTO, 2007). Aslında sürdürülebilir turizm, turizm planlaması ile doğrudan ilişkilidir. Nitekim 1995 yılında Lanzarote Dünya Konferansı'nda kabul edilen Sürdürülebilir Turizm Şartı ile sürdürülebilir turizmin temel bir ilkesi olarak entegre planlama ihtiyacı vurgulanmaktadır (Ransley, 2020). Benzer ilkeler, BM Sürdürülebilir Kalkınma Komisyonu, Seyahat ve Turizm Endüstrisi için Gündem 21 tarafindan da vurgulanmaktadır (WTO, 2004).

WTO, tanımlanmış taşıma kapasitesine bağlı arazi kullanım kararlarını da içeren yerel ve bölgesel planlamaların oluşturulmasını ve bu planlara turizm stratejilerinin entegre edilmesini sürdürülebilirlik için önemli görmektedir. Uzundere'de alan kullanımlarını düzenleyen bölgesel düzeyli 1/100 000 ölçekli çevre düzeni planı ve yerel düzeyli 1/1000 ölçekli uygulama imar planı bulunmaktadır. Bunun yanında doğal sit alanı olan Tortum Gölü çevresinde alan kullanımları ile ilgili kararları belirleyen koruma amaçlı imar planı vardır (Şekil 4 ). 


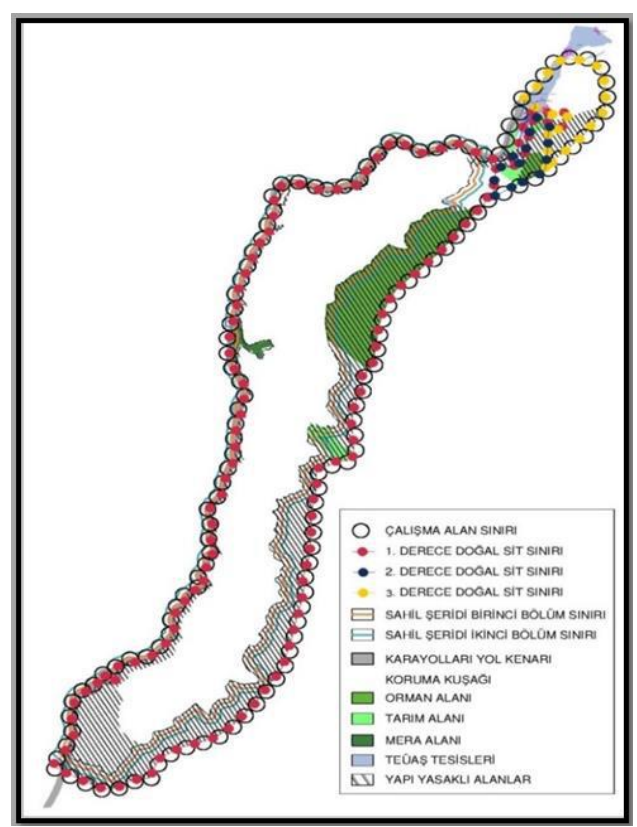

Şekil 4. Tortum Gölü koruma amaçlı imar planı sit alan sınırları

Demircioğlu Yıldız (2006) çalışmasında Tortum Çayı güzergahını rekreasyonel kullanım, Tortum Gölü ve Şelalesi ile yakın çevresini de korunması gereken alan olarak değerlendirmiştir. Ancak gerek bölgesel düzeyli, gerekse de yerel düzeyli stratejik planlamalarda Tortum Gölü ve Şelalesi'nin bulunduğu alanın, çeşitli rekreasyonel aktivitelerle birlikte turizm amaçlı değerlendirilmesi planlanmıştır. Nitekim Uzundere'de Tortum Gölü ve Tortum Şelalesi çevresinde fiyort park ve Uzunburun Yarımadası rekreasyon projesi uygulamaları ile Tortum Gölü ve Şelalesi peyzaj tasarımı gibi çalışmalar bulunmaktadır. Bu nedenle bu alandaki kullanımların koruma faaliyetleriyle desteklenmesi gerekmektedir. Uzundere'nin turizm arzını oluşturan en önemli kaynaklardan birisi olan bu alanın doğal ve kültürel peyzajını korumak, hem ekosistem içerisindeki işlevleri hem de turizmin sürdürülebilirliği açısından önemlidir. İlçenin imar planında konut için 2 ve 4 katlı yapı sınırı getirilmiştir. Özellikle eski kent dokusunun olduğu alanlar için ayrık nizam 2 katlı yapılaşma koşulu getirilmesi önemlidir. Ancak bu kırsal kültürün önemli bir parçası olan geleneksel mimarinin sürdürülebilirliği açısından tek başına yeterli değildir. Çünkü geleneksel mimari insana ait sosyal, ekonomik ve kültürel özelliklerin çevre ile olan ilişkisinin yansımasıdır. Bu ilişki geleneksel mimariye özgünlük kazandırmaktadır ve bunu sürdürülebilir hâle getirmek sadece yapı yüksekliği şartı getirerek mümkün olmayacaktır. Kut Görgün ve Yörür (2018), kırsal yerleşmeler için özgün dokunun korunması amaciyla tasarım rehberleri hazırlanması gerektiğini bildirmiştir. Uzundere için de doğal ve kültürel peyzaj özelliklerine dayalı olarak yapılaşmalara ait standartları belirleyen bir tasarım rehberi hazırlanması geleneksel kırsal dokunun sürdürülebilirliği bakımından yararlı olacaktır.

Uzundere'nin mekânsal planlama çalışmalarında dikkat çeken bir diğer nokta ise turizme yönelik bir alan kullanım kararı getirmemesidir. Bir turizm merkezi olarak mekânsal planlama çalışmalarında turizme yönelik kararların olmayışı sürdürülebilirlik açısından önemli bir eksikliktir. Çünkü sürdürülebilir turizm ile alan kullanım planlaması doğrudan ilişkili kavramlardır. Testoni (2001) turizmin olumsuz etkilerinin minimum seviyeye indirilmesi ve sürdürülebilir turizm gelişiminin sağlanmasında arazi kullanım planlamasının önemli bir rol üstlendiğini bildirmektedir. Tyrväinen et al., (2014), Finlandiya'nın doğaya dayalı bir turizm merkezi olan Lapland bölgesinde yaptığı araştırmada ziyaretçilerin otantik doğa manzaralarını ve yeşil altyapıyı önemsediklerini saptamıştır. Nitekim Özgeriş ve Karahan (2015) çalışmalarında Uzundere'deki ziyaretçilerin peyzaja ait doğal ve kültürel elemanların birbiriyle uyumlu ve bir bütünlük oluşturduğu manzaraları görsel olarak daha etkileyici bulduğunu ve ziyaretlerinde bu alanları tercih ettiğini değerlendirmiştir. Bu nedenle Uzundere gibi peyzaj özellikleri bakımından çeşitlilik ve etkileyici manzaralar içeren, ziyaretçiler için doğaya dayalı turizm deneyimleri sunan destinasyonlar için koruma statüleri de dikkate alınarak turizme yönelik alan kullanım planlaması yapılmalı ve mekânsal planlama çalışmaları bu yönde revize edilmelidir. Özellikle Uzundere vadisi boyunca yapılacak turizm tesisleri ve diğer yapılaşmalarda doğal peyzaj dokusunun korunması amacıyla, yapılaşmalar bir bütün oluşturacak şekilde planlanmalıdır. Bunun yanında yapılaşmalarda, yapı yüksekliklerinin peyzajın siluetini bozmayacak bir ölçüde olmasını, kullanılan malzemenin doğal 
çevre ile renk, doku ve malzeme cinsi bakımından uyumlu ve yapılan tesislerin gerek tasarım bakımından gerekse de işlevsel olarak birbirinin devamı niteliğinde olmasını ve yöreye özgü geleneksel mimari kültürünü yansıtmasını sağlayacak olan planlama kararları oluşturulmalıdır. Bu konuda Uzundere Turizm Master Planı'nda ilçe için konut ve turizm tesisi tasarım örnekleri sunulmuştur ve bu çalışmadaki tasarımlar yapılaşma için örnek alınabilir.

İzleme kriteri bakımından tüm çalışmalar düşük bir puan almıştır. Bu kriter bakımından oluşan anlamlı farklılıklar, Uzundere mevcut durum ile ulusal-bölgesel planlama çalışmaları arasında gerçekleşmiştir. Uzundere'nin sosyal, ekonomik ve çevresel olarak gösterge setine dayalı bir izleme sisteminin bulunmaması, planlama çalışmalarının ya da turizme yönelik yatırımlarının etki değerlendirmesinin yapılmasını ya da katkıya dayalı başarı düzeyinin belirlenmesini olanaksız kılmaktadır. Bu nedenle planlama çalışmalarının başarısı ile izleme ve değerlendirme sistemlerinin varlığı arasında pozitif bir ilişkinin olduğu şeklinde bir sonuca varılmıştır.

\section{SONUÇ:}

Bu çalışma Erzurum ilinin Uzundere ilçesinde yürütülmüştür. Uzundere'nin ulusal-bölgesel ve yerel planlama çalışmalarında iki ana kalkınma ekseninden biri turizmdir ve turizmde markalaşmış bir destinasyon olmayı hedeflemektedir. Bu hedefe yönelik olarak ilçe 2013 y1lında turizm merkezi ilan edilmiş ve 2016 y1lında Sakin Şehir ağına dahil olmuştur. İlçede yerel kalkınmanın bir aracı olarak turizm hareketliliği oluşturmak ve turizm gelişimini sağlamak için özellikle son 15 yılda kamu, yerel yönetim ve sivil toplum aracilığıly bir çok sosyo-ekonomik, mekânsal, stratejik planlama çalışması, araştırma raporu ve destinasyon oluşumuna yönelik programlar gerçekleştirilmiştir. Ancak tüm bu çalışmalar sürdürülebilir turizmin ihtiyaç duyduğu temel stratejilere ne derece sahip olduğu ve yerel kalkınmaya ne derece hizmet edebileceği konularında tartışmaları da beraberinde getirmiştir. Bu duruma yönelik olarak çalışma ile turizm ve yerel kalkınma bağlamında ilçenin ulusal-bölgesel ve yerel planlama çalışmaları ile ilçenin mevcut durumu sürdürülebilirlik çerçevesinde değerlendirilmiştir. $\mathrm{Bu}$ kapsamda 'Sürdürülebilirlik Değerlendirmesi Çalışma Formu' oluşturularak odak grup çalışması yapılmıştır.

Çalışmanın sonuçlarına göre ilçenin gelişme ve kalkınma perspektifini belirlemede etkili olan ulusal-bölgesel ve yerel planlama çalışmaları ile ilçenin mevcut durumu odak grup tarafından birçok kriter bakımından yerel kalkınma ve turizm bağlamında sürdürülebilir olarak değerlendirilmemiştir. Bunun yanında yerel planlama çalışmaları bazı konularda sürdürülebilirliğe hizmet edebilecek strateji ve tedbirlere sahip olmasına rağmen, bu strateji ve tedbirlerin uygulamaya geçirilemediği belirlenmiştir. $\mathrm{Bu}$ durumun planlama çalışmalarının uygulamalardaki karşılı̆̆ının belirlenmesini sağlayacak olan izleme ve değerlendirme sisteminin olmayışından kaynaklanabileceği değerlendirilmiştir.

Sürdürülebilirlik kavramı sosyo-kültürel, çevresel ve ekonomik olmak üzere tüm boyutlarıyla bir bütün olarak düşünülmesi ve içerisinde ekolojik yaklaşımları ve çevresel duyarlılıkları da barındırması gereken geniş kapsamlı bir kavramdır. Turizmin sürdürülebilir gelişimi de sürdürülebilirliğin tüm boyutları ile ele alınarak ve yerel kalkınmanın bir aracı olarak düşünülerek gerçekleştirilebilir. Bu ise ancak planlama çalışmalarına yerel halk, yerel çevre, ziyaretçi memnuniyeti ve organizasyon, yönetim ve izleme konularında sürdürülebilir turizmin ön gördüğü temel stratejileri geliştirerek ve tüm paydaşları sürece dahil ederek yapılacak olan geniş katılımlı bütüncül yaklaşımlar ile mümkün olabilir. Aksi bir turizm gelişimi, sürdürülebilir olmaktan ve yerel kalkınmaya hizmet etmekten uzak olacaktır.

\section{Etik Standart ile Uyumluluk}

Çıkar Çatışması: Yazarlar herhangi bir çıkar çatışmasının olmadığını beyan eder.

Etik Kurul İzni: Bu çalışma için etik kurul iznine gerek yoktur.

Finansal Destek: Herhangi bir finansal destek alınmamıştır.

\section{KAYNAKÇA:}

Acuner, E., (2015). Zigana Turizm Merkezi'nin Sürdürülebilir Turizm Kriterleri Çerçevesinde Yerel Destinasyon Yönetim Örgütleri Tarafindan Değerlendirilmesi. Gazi Üniversitesi Turizm Fakültesi Dergisi 1 (2015), 6293. 
Anonim, (2013). Erzurum Doğa Turizmi Master Planı 2013-2023. Orman ve Su İşleri Bakanlığı Doğa Koruma ve Milli Parklar Genel Müdürlüğü,119 s, Erzurum.

Anonymous, (1987). Report of the World Commission on Environment and Development: Our Common Future. http://www.un-documents.net/our-common-future.pdf (07.08.2020).

Bahtiyar Karadeniz, C., (2014). Sürdürülebilir Turizm Bağlamında Sakin Şehir Perşembe. Uluslararası Sosyal Araştırmalar Dergisi, 7 (29), 84-107.

CEPF, (2003). Critical Ecosystem Partnership Fund. Ecosystem Profile, Caucasus Bioiversity Hotspot. https://www.cepf.net/our-work/biodi versi tyhot spots /cauca sus. (30.08.2020).

Çakmak, E., (2010). Uzundere Stratejik Gelişme Planı: Vizyon 2023. 82 s, Erzurum, Türkiye.

Demircioğlu Yıldız, N., (2006). Tortum Çayı Havzasının Uygun Alan Kullanımlarının CBS ile Belirlenmesi. Doktora Tezi, Atatürk Üniversitesi Fen Bilimleri Enstitüsü, Erzurum.

Denzin, N.K., Lincoln, Y.S., (2008). The Landscape of Qualitative Research. Sage Publications, 615 p., London. ISBN: 978-1-4129-5758-8.

Farsani, N.T., Coelho, C., Costa, C., (2011). Geotourism and geoparks as novel strategies for socio-economic development in rural areas. International Journal of Tourism Research, 13(1), 68-81.

Holloway, J.C., (2009). The Business of Tourism (8 ed.). Harlow: Pearson Education, 776 p, England.

Inskeep, E., (1991). Tourism planning: An integrated and sustainable development approach. 40 p, New York: Van Nostrand Reinhold.

İpar, S., Doğan, M., (2013). Destinasyonun Turist Açısından Önem-Memnuniyet Modeli ile Dĕ̆erlendirilmesi: Edremit Üzerine Bir Uygulama. Adıyaman Üniversitesi Sosyal Bilimler Enstitüsü Dergisi, 6 (13), 129-154.

Karahan, F., Çil, A., Ercişli, S., (2017). Uzundere Biyolojik Çeşitlilik Stratejisi ve Eylem Planı (2017-2023). Erzurum, 191 s, Türkiye. ISBN: 978-605-65712-5-1

Karahan, F., Kopar, İ., Orhan, T., Çakır, E., (2011). The geopark potential of Tortum Valley (Erzurum-Turkey) and its surroundings. In Natural environment and culture in the Mediterranean Region II (pp.395-407). Newcastle: Cambridge Scholars Publishing.

Karakurt Tosun, E., (2013). Yaşam Kalitesi Ekseninde Şekillenen Alternatif Bir Kentsel Yaşam Modeli: Yavaş Kentleşme Hareketi. Uludağ Üniversitesi İktisadi ve İdari Bilimler Fakültesi Dergisi, 32 (1), 215-237.

Kaypak, Ş., (2011). Küreselleşme Sürecinde Sürdürülebilir Bir Kalkınma Iç̧in Sürdürülebilir Bir Çevre. KMÜ Sosyal ve Ekonomik Araştırmalar Dergisi, 13 (20): 19-33.

Kopar, İ., Çakır, Ç., (2013). Determination of Geo-diversity of Lake Tortum-Tortum Gorge Valley and Surrounding Places (Uzundere-Erzurum and Yusufeli-Artvin) through Serrano and Ruiz-Flaño Method. İ.Ü. Coğrafya Dergisi, 27, 46-66.

Kopar, İ., Sevindi, C., (2013). Tortum Gölü’nün (Uzundere-Erzurum) Güneybatısında Aktüel Sedimantasyon ve Siltasyona Bă̆lı Alan-Kıyı Çizgisi Değişsimleri. Türk Coğ. Derg., 60, 49-66.

Kozak, M., (2001). Comparative Assessment of Tourist Satisfaction with Destinations Across Two Nationalities. Tourist Management, 22, 391-401.

Kozak, M.A., Bahçe, S., (2009). Özel İlgi Turizmi. Detay Yayıncılık, 320 s, Ankara.

Kut Görgün, E., Yörür, N., (2018). Kırsal Yerleşmelerde Özgün Dokunun Korunmasında Bir Araç Olarak Köy Tasarım Rehberleri: Ödemiş Bademli Örneği. TÜBA-KED, 17, 25-46.

Miele, M., (2008). Cittaslow: Producing Slowness against the Fast Life. Space and Polity, 12, (1), 135-156.

Özgeriş, M., Karahan, F., (2015). Rekreasyonel tesislerde görsel kalite değerlendirmesi üzerine bir araştırma: Tortum ve Uzundere (Erzurum) örneği. Artvin Çoruh Üniversitesi Orman Fakültesi Dergisi, 16 (1), 40-49.

Özgeriş, M., (2020). Sakin Şehir Uzundere’nin Planlama ve Tasarım Uygulamaları Yönünden Sürdürülebilirliğinin Değerlendirilmesi. Doktora Tezi, Atatürk Üniversitesi Fen Bilimleri Enstitüsü, Erzurum.

Özgeriş M., Karahan, F., (2020). Use of geopark resource values for a sustainable tourism: a case study from Turkey (Cittaslow Uzundere). Environment, Development and Sustainability. https://doi.org/10.1007/s10668-02000773-3

Özkök, F., Gümüş, F., (2009). Sürdürülebilir turizmde bilginin önemi. Yönetim Bilimleri Dergisi, 7(1), 51-71.

Page, S.J., Connell, J., (2006). Tourism: a modern synthesis. Thomson, 546 p, London.

Ransley, M., (2012). Sustainable Tourism Practices. https://www.academia.edu/4820716/ Sustainable_Tourism_Practices $(10.09 .2020)$

Resmi Gazete, (2020). Resmi Gazete. https://www.resmigazete.gov.tr/eskiler/2013/10/20131006-3.htm (10.09.2020).

SBB, (2020). Cumhurbaşkanlığı Strateji ve Bütçe Başkanlığı. 11. Kalkınma Planı. http://www.sbb.gov.tr/wpcontent/uploads/2019/07/OnbirinciKalkinmaPlani.pdf (13.09.2020) 
Şahin, İ., Kutlu, S.Z., (2014). Cittaslow: Sürdürülebilir Kalkinma Ekseninde Bir Değerlendirme. Journal of Tourism and Gastronomy Studies 2 (1), 55-63.

Şahin Z., (2017). Aktüel Turizm Türü Olarak Cittaslow Organizasyonu, Türkiye ve Dünyadaki Örnekleriyle Cittaslow Faaliyetlerinin Pazarlaması Açısından Bir Swot Analizi. Yüksek Lisans Tezi, Beykent Üniversitesi Sosyal Bilimler Enstitüsü, İstanbul.

Testoni, L., (2001). Planning for Sustainable Tourism. Pacific Tourism Review, 4 (4), 191-199.

Tıraş, H.H., (2012). Sürdürülebilir Kalkınma ve Çevre: Teorik Bir İnceleme. Kahramanmaraş Sütçü İmam Üniversitesi İktisadi ve İdari Bilimler Fakültesi Dergisi, 2 (2), 57-73.

TÜIK, (2014). Seçilmiş Göstergelerle Erzurum. TÜİK Matbaası, 183 s, Ankara.

Tyrväinen, L., Uusitalo, M., Silvennoinen, H., Hasu, E., (2014). Towards sustainable growth in nature-based tourism destinations: Clients' views of land use options in Finnish Lapland. Landscape and Urban Planning, 122 (February), 1-15.

UNEP and WTO, (2005). United Nations Environment Programme and World Tourism Organization. Making Tourism More Sustainable: A Guide for Policy Makers. http://www.unep.fr/shared/publications/pdf/dtix0592xpa-tourismpolicyen.pdf (01.08.2020)

UNWTO, (2007). Sustainable Tourism Indicators and Destination Management. https://sdt. unwto.org/sites/all/files/pdf/finrep.pdf (01.08.2020)

Uzundere Kaymakamlığı, (2018a). Uzundere Kaymakamlığı Gıda Tarım ve Hayvancıllk İlçe Müdürlü̆̆̈̈ Verileri. http://www.uzundere.gov.tr/gida-tarim-ve-hayvancilik-mudurlugu1 (01.05.2018).

Uzundere Kaymakamlığı, (2018b). Uzundere Kaymakamlığı. http://www.uzundere.gov.tr/ (06.02.2018).

Wei, F., (2014). Compendium of Best Practices in Sustainable Tourism, Prepared for United Nations Department of Economic and Social Affairs. https://sustainabledevelopment. un.org/content/documents/3322Compendium\%20of\%20Best\%20Practices\%20in\%20Sustainable\%20Touris m\%20\%20Fen\%20Wei\%2001032014.pdf (20.09.2020)

WTO, (2004). Indicators of Sustainable Development for Tourism Destinations: A Guidebook. 507 p, Madrid. 